DOI: $\underline{10.15826 / j \operatorname{tr} .2018 .4 .1 .045}$

\title{
Road traffic taxation in Germany: the present system, its problems and a proposal for reform
}

\author{
Fritz Söllner \\ Ilmenau Technical University, Ilmenau, Germany \\ ORCID: 0000-0003-1047-6662
}

\begin{abstract}
This article examines the taxation of road traffic in Germany and makes a proposal for its reform. The policy-oriented approach used here is inspired by the tradition of economists like Richard A. Musgrave in the United States or Günter Schmölders in Germany who always sought to integrate fiscal theory and fiscal practice. Thus, our considerations are guided by three basic principles of taxation which are well-founded theoretically and, at the same time, flexible enough to deal with issues of policy: fairness, efficiency and practicability. They are used, at first, to show what a systematic taxation of road traffic would look like. Then, actual road traffic taxation in Germany is described and measured against this standard. It turns out that none of the different road traffic taxes or fees in Germany conform to the principles of taxation. Therefore, finally, a proposal for reform is made which is discussed not only in terms of fairness and efficiency but also in terms of political acceptability and of compatibility with European law. It is found that the reform proposed complies with the principles of taxation and European law, but that, at present, it may be difficult to win public acceptance for one of its parts
\end{abstract}

\section{KEYWORDS}

Road traffic taxation, principles of taxation, user fees, tolls, steering taxes, emission taxes, $\mathrm{CO}_{2}$ taxes

\section{JEL H23, H54, Q52, Q53}

\section{HIGHLIGHTS}

1. It is argued that road traffic taxation, like taxation in general, ought to follow certain basic principles, such as fairness, efficiency or practicability. According to these principles, taxes on road traffic can only be justified in the form of fees paid by road users and in the form of steering taxes in order to combat air pollution and congestion

2. Since road traffic taxation in Germany does not comply with the principles of taxation, a proposal for reform is put forward. As a first step, the motor vehicle tax is to be abolished and the energy tax is to be transformed into a tax on $\mathrm{CO}_{2}$ emissions; as a second step, the truck toll and the infrastructure charge are to be merged into a comprehensive toll

3. A European approach to the reform of road traffic taxation is needed, because any unilateral reform may possibly cause competitive disadvantages for German transport companies and obstacles to the flow of traffic in Europe

УДК: 336.231:336.221.2

\section{Налогообложение дорожного Авижения в Германии: современные проблемы и планы реформирования}

\author{
Ф. Золльнер \\ Технический университет Ильменау, г. Ильменау, Германия \\ ORCID: 0000-0003-1047-6662
}

\begin{abstract}
АННОТАЦИЯ
Статья посвящена изучению налогообложения дорожного движения в Германии и разработке предложений по его реформированию. В исследовании использован политико-ориентированный подход, соединяющий фискальную теорию и фискальную практику. Данный подход продолжает традиции таких исследователей как Ричард Масгрейв (США) и Гюнтер Шмольдер (Германия). Поставлен вопрос о соответствие налогообложения дорожного движения в Германии трем
\end{abstract}


основным принципам налогообложения: справедливости, эффективности и практичности. Первоначально рассматривается, каким образом может налогообложение дорожного движения воплощать данные принципы, а затем, анализируется соответствие этим принципам налогов и сборов, составляющих систему налогообложения дорожного движения в Германии. Рассматриваются два налога (энергетический налог и налог на автотранспорт) и два сбора (дорожный сбор для грузовых транспортных средств и плата за инфраструктуру). Сделан вывод, что ни один из представленных налогов и сборов не соответствует основным принципам налогообложения. На основе исследования предлагается реформирование налогов и сборов, связанных с дорожным движением в Германии. Анализируются перспективы предлагаемых изменений, их фискальные и экономические последствия. Предлагаемые изменения обсуждаются как с точки зрения их справедливости и эффективности, так и с точки зрения политической приемлемости и совместимости с европейским законодательством. Установлено, что предложенная реформа соответствует принципам налогообложения и европейского права, но труднореализуема в настоящее время

\section{КЛЮЧЕВЫЕ СЛОВА}

Налогообложение дорожного движения, принципы налогообложения, сбор с пользователя; дорожные пошлины; регулирующие налоги; налоги на выбросы; налоги на $\mathrm{CO}_{2}$

\section{ОСНОВНЫЕ ПОЛОЖЕНИЯ}

1. В соответствие с основными принципами налогообложения (справедливость, эффективность и практичность), участники дорожного движения должны уплачивать только регулирующие налоги и сборы для борьбы с загрязнением воздуха и дорожными пробками

2. Поскольку налогообложение дорожного движения в Германии не соответствует основным принципам налогообложения, предлагается, во-первых, отменить налог на автотранспорт и преобразовать энергетический налог в налог на выбросы $\mathrm{CO}_{2}$; во-вторых, объединить дорожный сбор для грузовых транспортных средств и плату за инфраструктуру в единый сбор

3. Реформа налогообложения в области дорожного движения должна соответствовать общеевропейским подходам, поскольку любая односторонняя реформа может ухудшить конкурентные позиции немецких транспортных компаний и создать препятствия для дорожного движения в Европе

\section{Introduction}

In recent years, the internal combustion engine in general and the diesel engine in particular have more and more fallen into disrepute. The use of internal combustion engines in motor vehicles is being criticized for their release of the greenhouse gas $\mathrm{CO}_{2}$ and, thus, their contribution to climate change. In addition, automakers have come under fire for the wide discrepancies between the "official" emission and fuel consumption figures determined on the dynamometer and the (much) higher figures under real driving conditions. The image of the diesel engine has suffered most - firstly, because of the diesel scandal due to the illegal use by the Volkswagen group of default devices with which emissions testing was manipulated and, secondly, because diesel cars and trucks are blamed for excessive concentra- tions of nitrogen oxides in the air of city centers and threatened to be banned from major cities. These days, the diesel engine is no longer seen as a reliable, durable and economical engine but as a major source of pollution. This has already led to a decline in the sale of new diesel cars and to losses in the market value of used diesel cars. Furthermore, the different tax rates for diesel and gasoline under the Energy Tax Code (formerly: Petroleum Tax Code) have been criticized. For example, the head of the Umweltbundesamt (Federal Agency for the Environment), Maria Krautzberger, called the lower tax rate for diesel an unwarranted subsidy and demanded "the abolition of the diesel privilege granted by the Petroleum Tax Code" [1, my translation]. Similarly, Dudenhöffer suggests "to quickly adapt the taxation of diesel to the taxation of gasoline and, at the same time, 
to harmonize motor vehicle taxes on diesel cars and gasoline cars" [2, my translation].

In view of the above-mentioned problems such proposals seem to be justified and plausible. However, simply equalizing the tax rates for diesel and gasoline by, for example, raising the former to the level of the latter, would be inadequate as will be shown below. For us, the discussion about the diesel engine and the taxation of fossil fuels will serve only as the starting point for the examination of road traffic taxation in general. In the present paper, a systemic view of tax reform shall be adopted - a view that is to be guided by certain basic principles of taxation. These principles shall be drawn upon, firstly, to criticize the present system of road traffic taxation in Germany and, secondly, to derive proposals for the reform of this system - the objective being a system of road traffic taxation which is both consistent and economically efficient.

But, first of all, we need to sketch the present system of road traffic taxation in Germany and point out its shortcomings.

\section{The taxation of road traffic in Germany: The present situation}

Presently, road traffic in Germany is subject to two particular taxes: the energy tax and the motor vehicle tax. Both are federal taxes, that is, their revenue is due to the federal government.

In 2006 the petroleum tax was merged into the new energy tax which applies not only to petroleum products like gasoline, diesel or fuel oil but also to coal, natural gas and biofuels. For road traffic, mainly the tax rates for gasoline and for diesel are relevant. Less important for road traffic are other fossil fuels like natural gas or liquified petroleum gas which shall be mentioned only in passing. The energy tax amounts to $€ 0.6545$ per liter of gasoline (unleaded, low-sulfur) and $€ 0.4708$ per liter of diesel (low-sulfur) (§ 2, par. 1, nos. 1, 4 Energy Tax Code). The higher tax rates for diesel and gasoline with a sulfur content of more than $10 \mathrm{mg} / \mathrm{kg}$ are all but irrelevant since the market share of these fuels is below 0.1 $\%$. The higher tax rate for leaded gasoline can be neglected too, since it is almost ex- clusively used as an aviation fuel - and not for road traffic anymore [3]. Insofar as fuel is purchased by households (and not by business firms) the effective tax burden is increased by the value-added tax (VAT) which is imposed on the total net price and which, therefore, is imposed also on the energy tax which is part of the net price of fuel. With the VAT rate currently standing at $19 \%$, this increase amounts to $€ 0.1244$ or $€ 0.0894$ per liter of gasoline or diesel, respectively. This assumes, as is usual, that the energy tax is completely shifted forward to the buyers of fossil fuels. (The energy tax on natural gas is $€ 13.90$ per MWh of thermal value (§ 2, par. 2, no. 7a Energy Tax Code).) The thermal value of natural gas being $12.87 \mathrm{~kW}$ per kilogram, this is equivalent to an energy tax of $€ 0.1789$ per kilogram of natural gas (natural gas is sold by mass, not by volume); the VAT applying to this tax amounts to $€ 0.0340$ per kilogram.)

Whether the fact that diesel is taxed at a lower rate than gasoline is called a subsidy of diesel or the different taxation of different tax bases is only a matter of semantics which might be used as a political argument, but which is irrelevant for economic analysis.

Energy tax revenue in 2016 amounted to $€ 40.091$ billion - of which the tax on unleaded, low-sulfur gasoline and on lowsulfur diesel contributed $€ 15.868$ billion and $€ 20.849$ billion, respectively. (In comparison, the taxation of natural tax used for motor vehicles yielded only $€ 0.004$ billion [3].)

The motor vehicle tax, which is levied on an annual basis, uses different tax bases for the different kinds of motor vehicles. Here, we shall be concerned only with cars and heavy trucks (with a permissible total weight of more than $3,500 \mathrm{~kg}$ ). For cars with gasoline engines, newly registered since January $1^{\text {st }}, 2014$, the tax rate is $€ 2.00$ for every $100 \mathrm{~cm}^{3}$ of engine capacity plus $€ 2.00$ for every gram of the $\mathrm{CO}_{2}$ emission per kilometer in excess of $95 \mathrm{~g} / \mathrm{km} . \mathrm{CO}_{2}$ emissions are determined by a dynamometer test which is standardized within the EU. (Cars which run on natural gas are taxed like those which run 
on gasoline.) In the case of diesel cars the tax component based on engine capacity rises to $€ 9.50$ for every $100 \mathrm{~cm}^{3}$, but the tax component based on $\mathrm{CO}_{2}$ emissions stays the same ( $\S 9$, par. 1 , no. 2 b Motor Vehicle Tax Code). Trucks are taxed in accordance with permissible total weight and the amount of emissions and noise they produce. For the computation of the tax the so-called "graduated tax-rate method" is used; in addition, there is an upper limit to the total tax due ( $\$ 9$, par. 1, no. 4 Motor Vehicle Tax Code). For example, the maximal tax for trucks belonging to emissions class S2 (S1) is $€ 556.00$ $(€$ 914.00) - amounts which are of the same order of magnitude as those for cars with big diesel engines (for example, the motor vehicle tax for a Range Rover 4.4 SDV8 is $€ 666.00$ ). Motor vehicle tax revenue in 2016 was $€ 8.952$ billion; there is no current data on the respective shares of cars, trucks and other vehicle categories but, if data from the recent past is any indication, cars will have contributed more than $80 \%$ of total revenue $[4 ; 5]$.

As can be seen from Table $1[3 ; 4]$ there have been only insignificant changes in both energy tax and vehicle tax revenue during the last ten years; furthermore, the energy tax on unleaded, low-sulfur gasoline and low-sulfur diesel has always been the most important part of the energy tax (accounting for more than $80 \%$ of total energy tax revenue in each year).

Energy Tax Revenue in Germany 2007-2016

\begin{tabular}{|l|r|r|c|}
\hline \multirow{2}{*}{ Year } & \multicolumn{2}{|c|}{$\begin{array}{c}\text { Energy Tax Revenue } \\
\text { in billions of Euros }\end{array}$} & $\begin{array}{c}\text { Vehicle } \\
\text { Tax } \\
\text { Revenue }\end{array}$ \\
\cline { 3 - 4 } & total & $\begin{array}{c}\text { cunleaded, low- } \\
\text { sulfur gasoline and } \\
\text { low-sulfur diesel }\end{array}$ & $\begin{array}{c}\text { Rev billions } \\
\text { of Euros }\end{array}$ \\
\hline 2016 & 40.091 & 36.717 & 8.952 \\
\hline 2015 & 42.433 & 36.465 & 8.805 \\
\hline 2014 & 41.893 & 30.095 & 8.501 \\
\hline 2013 & 42.160 & 35.410 & 8.490 \\
\hline 2012 & 42.115 & 35.457 & 8.443 \\
\hline 2011 & 41.985 & 36.068 & 8.422 \\
\hline 2010 & 43.025 & 35.719 & 8.488 \\
\hline 2009 & 41.238 & 34.759 & 8.201 \\
\hline 2008 & 41.418 & 35.137 & 8.842 \\
\hline 2007 & 41.712 & 35.080 & 8.898 \\
\hline
\end{tabular}

Comparing the total tax burden of cars, it is obvious that cars with gasoline engines are hit harder by the energy tax than cars with diesel engines, whereas the motor vehicle tax is lower for the former than for the latter. Since the motor vehicle tax is a fixed cost and the energy tax is a variable cost (with only the latter depending on mileage), the total tax burden per kilometer (or mile) for diesel and for gasoline cars compares as follows: For low mileages the total tax per kilometer is lower for gasoline than for diesel cars and vice versa for high mileages. At what mileage exactly a car with a diesel engine becomes cheaper in terms of taxes than a car with a gasoline engine depends on the car model considered, of course. This difference in taxation is due to the policy of avoiding high tax burdens for vehicles used by businesses (such as taxi and transport companies) which almost exclusively are equipped with diesel engines and whose annual mileage is, in most cases, very high. This policy is aimed at longhaul transport companies, in particular, which are subject to international competition and which would suffer from competitive disadvantages, if the energy tax on diesel were higher (at present, it is at about the European average). It is for that reason also that the motor vehicle tax on trucks is very low in comparison to that on cars.

In addition to these two taxes, there are also two traffic-related user fees: the truck toll and the infrastructure charge. Heavy trucks (with a permissible total weight of at least 7,500 kg) are subject to a toll which is collected on highways and major federal roads. The toll rate depends on the number of axles of a truck and its trailer and on the emission class; at present, it varies between $€ 0.125$ and $€ 0.214$ per kilometer. The infrastructure charge applies only to cars. It is a lump-sum charge that depends on engine capacity and emission class but not on mileage. German car owners have to pay it annually while foreigners using German roads are charged pro rata temporis. The infrastructure charge has already been enacted but is not levied yet because several suits against it brought by other EU members 
are still pending in the European Court of Law. The plaintiffs accuse Germany of discriminating against foreign drivers because German drivers will be compensated for the infrastructure charge by a rebate on the motor vehicle tax so that in effect only foreign drivers will be burdened [6].

The revenue of both the truck toll and the infrastructure charge is due to the federal government. The latter has not yet generated any revenue; the development of the revenue of the former is shown in table 2 [source of data: personal communication from the Federal Ministry of Transport and Digital Infrastructure].

Table 2

Truck Toll Revenue in Germany 2007-2016

\begin{tabular}{|c|r|}
\hline Year & $\begin{array}{c}\text { Truck Toll Revenue in billions } \\
\text { of Euros }\end{array}$ \\
\hline 2016 & 4.634 \\
\hline 2015 & 4.372 \\
\hline 2014 & 4.457 \\
\hline 2013 & 4.389 \\
\hline 2012 & 4.364 \\
\hline 2011 & 4.475 \\
\hline 2010 & 4.511 \\
\hline 2009 & 4.327 \\
\hline 2008 & 3.490 \\
\hline 2007 & 3.308 \\
\hline
\end{tabular}

Henceforth, the term "tax" shall be interpreted broadly - so as to include not only taxes in the narrow sense but also fees and charges.

\section{The principles of taxation}

In order for a tax system to be truly systematic - and not just a haphazard collection of various, unrelated and uncoordinated, taxes - it has to be governed by certain basic principles. At least since the time of Adam Smith, economists and political philosophers have put forward catalogues of principles that "good" tax systems are required to follow. It is neither possible nor necessary to discuss these catalogues in any detail here. Instead, only those very basic principles which seem to enjoy (almost) unanimous approval shall be considered [for the principles of taxation see, e.g., 7, p. 408; 8, pp. 224-225; 9, pp. 197-206].

Firstly, the tax burden ought to be distributed equitably among taxpayers - or, rather, since there is no objective standard of equity, the distribution of the tax burden ought to be perceived and accepted as equitable. Fairness can be realized by either the ability-to-pay or the benefit principle - with the former being today the predominant principle of taxation and the latter only playing a subsidiary role. Secondly, insofar as taxes are used to achieve objectives of economic policy, they ought to be compatible with these objectives, that is, they must be so designed as to realize the objectives effectively and efficiently. And, thirdly, administration and compliance costs ought to be as low as possible, to wit, as low as is compatible with other, higher-ranking objectives.

These three principles may also be characterized as follows: The first one is concerned with distribution or fairness; the second one with allocation or efficiency; and the third one with practicability.

Obviously, a policy-oriented approach is being followed here. Instead of aiming for the elusive objective of a social optimum, time-honored and commonsensical principles of taxation are appealed to. Thus, it will be possible to accommodate flexibly the different aspects of tax policy - from efficiency and distribution to feasibility and acceptability. In this way, possible conflicts, and the trade-offs that then are necessary, can be made explicit. This may not be the most rigorous approach but, then again, it is not the most inapplicable either. Let us now see what implications our principles have for the taxation of road traffic.

\section{Fairne]ss:}

ability-to-pay vs. benefit principle

Like all taxes, taxes on road traffic may have two purposes: to raise revenue or to influence the behavior of tax payers. Insofar as the former is the only (or main) purpose, fairness is the most important criterion to be fulfilled. Obviously, in the context of taxes on road traffic, the ability-to-pay principle is inapplicable. Income being the generally accepted measure of ability to pay at present, it is not compatible with the ability-topay principle to tax both income and consumption. To do so would result in double taxation, that is, the taxation of both the 
potential satisfaction of wants (income) and the actual satisfaction of wants (consumption). Thus, taxes on consumption cannot be justified by invoking the ability-to-pay principle, if income is used as a measure of ability to pay. This also goes for taxes on road traffic which, by definition, are taxes on consumption in one way or another.

On the other hand, these taxes may be compatible with the benefit principle, insofar as they can be regarded as "prices" to be paid for public services - in this case, for the provision and maintenance of the road infrastructure, the main users of which are motor vehicles. The benefit principle, as applied to the costs of public services (and not to the utility derived from them) demands that the contributions paid be equivalent (or as nearly so as possible) to the costs of the public services enjoyed. However, earmarking certain revenues for certain expenditures is not required, although this would seem to be an implication of the benefit principle.

The quantity and quality of road infrastructure that is needed depends primarily on the total mileage of all motor vehicles which in turn is the product of the number of motor vehicles and their average mileage. The wear and tear of roads and thus the expenditure necessary for their maintenance also depends on total mileage and, besides, on the weight of motor vehicles. The differences in weight between various motor vehicles only matter, though, if they are very large - such as those between cars and heavy trucks: With cars weighing mostly between 1,000 and $2,500 \mathrm{~kg}$, there is hardly any difference in road wear, if a light and a heavy car are compared with each other; but road wear will be found to increase disproportionately, if one consider cars, on the one hand, and heavy trucks, on the other.

If road infrastructure were to be financed in strict accordance with the benefit principle, a toll which takes mileage and, in addition, vehicle weight into account would be the only possible alternative. Ideally, such a toll would be collected for the use of all kinds of roads - with the toll per kilometer depending on the weight (or, rather, the weight class) of the respective vehicle. Due to recent technological advances (such as GPS navigation, electronic metering technology, mobile internet connections), such an ideal toll could be realized today without prohibitive costs: Tolls would be deducted electronically by way of in-vehicle transponders. The main obstacle seems to be a political one: How can the privacy of drivers be protected and how can undue surveillance by the state be prevented?

\section{Efficiency: steering taxes}

Road traffic taxation may not only (or not primarily) aim at raising revenue instead, its main objective may be to influence the behavior of taxpayers in accordance with economic policy objectives.

As (motorized) road traffic is the source of many negative externalities, it stands to reason that traffic-related steering taxes ought to be geared towards the internalization or reduction of these negative external effects. According to our policy-oriented approach, we do not advocate for the complete internalization of external effects. Instead, they are to be reduced in accordance with politically determined objectives (which may, or may not, be "optimal" from a welfare-theoretic point of view). In other words, our traffic-related steering taxes are not supposed to be "optimal" Pigou taxes but, less ambitiously, merely cost-efficient taxes in the tradition of the "standards and price" approach as pioneered by Baumol and Oates [10].

There are two major classes of externalities due to road traffic: the effects of congestion (in particular, the time lost in traffic jams) and the effects of air pollution. Besides, other kinds of external effects may exist, but they are either of minor importance or do not seem to lend themselves to the use of taxes [for a discussion of the externalities related to road traffic see, e.g., 11 and 12].

Let us first turn to congestion. On heavily travelled or even congested roads drivers impose externalities on one another because every driver contributes to congestion by slowing down the speed of all others; thus he increases the travel time for all others. Efficiency requires that motorists 
take these effects into account, which can be accomplished by levying a congestion charge. This charge ought to vary according to traffic intensity which itself depends on road location and travel time. For example, for rural roads there would be no congestion charge at all. On the other hand, in urban areas a congestion charge would be collected which would be highest during rush hour and lowest (possibly zero) in the middle of the night. Ideally, one might in addition differentiate the charge according to vehicle length (the longer a vehicle is, the more of the road it uses and the more it contributes to congestion), so that trucks would have to pay a higher charge than cars. Though such congestion charges have been introduced in some few cities - e.g., London and Stockholm -, a nationwide congestion charge does not yet exist anywhere. In practice, such a system might be combined with a general road toll (see above); the congestion charge might be added to the toll as a surcharge to be paid only on certain roads and at certain times. Such an extended road toll would then consist of two components: a fee-like component that is to finance road infrastructure (at least partly), and a tax-like component that is to discourage drivers from congesting roads. As mentioned above, such a scheme would be technically feasible nowadays, but privacy concerns would make its introduction politically difficult.

The second major class of traffic-related externalities is caused by air pollution. Motorized road traffic is one of the major sources of air pollution and thus responsible for many environmental problems and, in particular, serious risks for human health. Alternatively, one might consider another ecological objective - that of saving natural resources. But, at present, the main problem with the use of fossil fuels does not seem to be their exhaustibility but the environmental degradation resulting from the emission of pollutants. Road traffic is responsible for the emission of enormous quantities of air pollutants and thus for excess costs due to the negative external effects caused by these pollutants (in what follows we shall neglect the non-material emission of noise). To reduce these negative externalities to an acceptable level (which has to be determined politically), taxes or, to be more specific, emission taxes can be used. In fact, it is a well-established result of environmental economics that emission taxes have many advantages in comparison with the more traditional command and control approach. Both an ecologically effective and an economically efficient reduction of emissions can be achieved, if the quantities of pollutants released serve as tax bases so that the tax due results from the product of the tax rate (in monetary units per unit of emission) and the quantity of emissions. Conversely, if the emission of pollutants is to be reduced and if taxes are to be used for this purpose, they must be used in the form of (direct or indirect) emission taxes; taxes with bases other than the quantity of emission will hardly be able to be of much use [for emission taxes and the way they work, see, e.g., 10; 13, pp. 190210; 14, ch. 6; 15, part III].

Whether emission taxes are to be used depends a lot on the emissions we have to deal with. Therefore, let us have a look at the emissions of motorized vehicles. Pollutants in the narrow sense (i.e. pollutants which are directly inimical to human health) make up about $0.2 \%$ (diesel engines) or $1.1 \%$ (gasoline engines) of the total emissions of internal combustion engines [16; 17]. These "traditional" pollutants are nitrogen oxides, carbon monoxide, hydrocarbons, particulate matter and sulfur oxides. Except for sulfur oxides, these pollutants can be treated with devices such as three-way catalytic converters, oxidation catalytic converters, particulate filters, nitrogen oxide storage converters and SCR catalytic converters. Sulfur oxides cannot be treated with end-of-pipe technologies; their emission can only be reduced by reducing the sulfur content of fossil fuels. Beside the traditional pollutants, internal combustion engines emit nitrogen, oxygen, water vapour and carbon dioxide. The latter is a colourless, odourless, non-toxic and chemically very stable gas - and thus no pollutant in the narrow sense. However, $\mathrm{CO}_{2}$ is a greenhouse gas and - as such a climate pollutant: It may, due to its effects on the climate, cause externalities indirect- 
ly. In fact, the current level of $\mathrm{CO}_{2}$ releases into the atmosphere from the burning of fossil fuels is clearly incompatible with the stability of the climate and with sustainability. Therefore, without discussing climate policy in any detail, we may state that the emissions of $\mathrm{CO}_{2}$ need to be curtailed significantly, if potentially catastrophic developments are to be prevented. For our analysis, the following difference between traditional pollutants and the climate pollutant $\mathrm{CO}_{2}$ is most important: There is no direct relation between the emission of traditional pollutants and fuel consumption. A powerful engine with a sophisticated exhaust gas treatment may consume much more fuel and, at the same time, emit much fewer pollutants than a low-powered engine without any exhaust treatment. On the other hand, there does exist such a direct relation in the case of $\mathrm{CO}_{2}$ : The combustion of a certain quantity of a fossil fuel always leads to the emission of a certain quantity of $\mathrm{CO}_{2}$, which depends on the carbon content of the different fossil fuels; fuel consumption and $\mathrm{CO}_{2}$ emission are, for every type of fossil fuel, directly proportional to each other. Admittedly, there are minute divergences: An engine with a catalytic converter emits, e.g., less carbon monoxide and fewer hydrocarbons than an engine without a catalytic converter; and since these pollutants are oxidized to $\mathrm{CO}_{2}$ and $\mathrm{H}_{2} \mathrm{O}$ in the catalytic converter, the $\mathrm{CO}_{2}$ emission of the clean engine will be somewhat higher. But these divergences are so very small that they can safely be neglected for all practical purposes.
It is because of this proportionality that emissions can only in the case of $\mathrm{CO}_{2}$ be taxed indirectly. This means that emissions need not to be taxed themselves but that instead fuel consumption can be taxed. All other pollutants would have to be taxed directly, which would require measuring the quantities of the various pollutants emitted by every single motor vehicle. (What is more, the tax rates for the different pollutants would also have to depend on where they are emitted, because car exhaust is less dangerous and causes less damage on some little travelled country road than on an urban thoroughfare. In the case of $\mathrm{CO}_{2}$, on the other hand, the quantity of emissions is all that matters; the location of emissions is completely irrelevant.) Although technically feasible, this would be extremely costly. In addition, collecting these taxes would also be very expensive because measurement results would have to be transmitted regularly to tax authorities, which would then have to calculate tax bills and send them to the owners of motor vehicles. Therefore, considerations of cost and (im-) practicability require that traditional pollutants be dealt with by imposing regulations, that is, by using the command and control approach. (The same also goes for the emission of noise) On the other hand, the instrument of an emission tax can be applied to $\mathrm{CO}_{2}$ emissions because, in the form of an indirect tax, it causes only negligible administrative and compliance costs.

Figure shows the results of the discussion in the previous two sections.

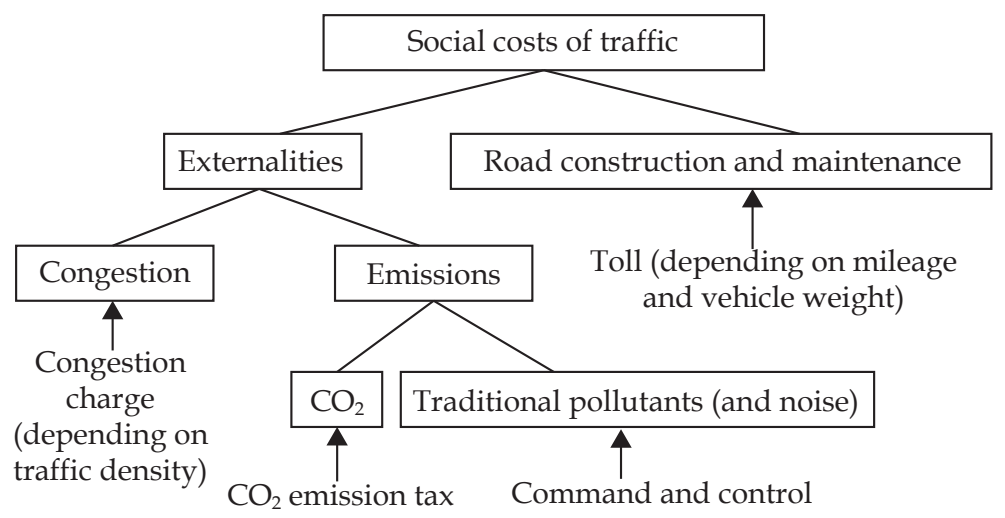

Social costs of traffic and how to deal with them 
Steering taxes (or tax-like charges) have an important role to play when it comes to dealing with congestion and $\mathrm{CO}_{2}$ emissions; they are less suited for reducing the emission of traditional pollutants (and noise). As regards fiscal taxes, the benefit principle may be invoked to justify the use of tolls for financing road infrastructure.

\section{Road traffic taxation in Germany and the principles of taxation}

As shown above, a system of taxes on road traffic can be derived from the principles of taxation. How do the actual taxes on road traffic in Germany compare to this system? It is obvious that it is quite different from our "ideal" system. How big the difference is and whether it complies at least in some degree with the principles of taxation shall be examined next.

\section{The benefit principle}

Since the ability-to-pay principle in inapplicable in the case of road taxation (see above), it is only the benefit principle that may be used to justify German road traffic taxes. Let us first have a look at the motor vehicle tax. It very quickly will become apparent that in this case the necessary equivalence between the cost of the public service and the amount to be contributed by its users does not even approximately exist: The amount of motor vehicle tax to be paid is completely independent of both mileage and weight in the case of cars. And, though taking weight into account, the motor vehicle tax on trucks disregards the much more important mileage: For example, even though a 10 ton truck with an annual mileage of 100,000 kilometers causes significantly more damage to roads than a 30 ton truck with an annual mileage of only 10,000 kilometers, the motor vehicle tax on the latter is higher than that on the former. Furthermore, the relation between the motor vehicle tax on cars and that on trucks is incompatible with the benefit principle: Since, because of their much higher weight and their much higher mileage, trucks wear out roads much more than cars, they ought to be taxed higher by orders of magnitude - which is certainly not the case at present.
The energy tax better complies with the benefit principle because a higher fuel consumption is, ceteris paribus, tantamount to a higher mileage and, thus, to more road wear. But even here, the relationship is rather weak. Driving style is a very important factor: An economical driver may, for example, be able to drive a distance of 1,500 kilometers with 100 liters of gas whereas a sports driver may only do 1,000 kilometers with the same car and the same quantity of fuel. The economical driver uses roads more than the sports driver but has to pay the same amount of energy tax (since, in our example, the fuel consumption is supposed to be the same). Even more important are differences between the various car models: A sport scar with a powerful engine that consumes 15 liters of gas per 100 kilometers does not cause three times as much road wear as a subcompact with a small engine that consumes only 5 liters of gas per $100 \mathrm{ki}$ lometers. The same arguments also apply to trucks - although in their case the differences with regard to engine power are less marked. Therefore, also the energy tax cannot be justified by invoking the benefit principle. This conclusion is, by the way, not affected by the earmarking of part of the energy tax revenue (formerly: petroleum tax revenue) for road construction which, besides, has been attenuated and de facto abandoned since the 1970s [18].

As we have seen, a road toll is the fiscal instrument which complies best with the benefit principle. In Germany, there is a toll for heavy trucks and, for cars, there is to be the "infrastructure charge" (see above). Both can by no means meet the demands of the benefit principle. The former is collected not on all roads but only on highways and certain federal roads. Furthermore, vehicle weight is taken into account only indirectly (by the toll rate being dependent on the number of axles). In addition, the toll rate also depends on the emission class - which, however, does not affect road wear at all. The infrastructure charge fares even worse, as it is completely independent of mileage. However, it might serve as a first step towards a "real" toll [6]. 


\section{Steering taxes and the allocative function of road traffic taxation}

As the present taxes on road traffic in Germany cannot be justified by the benefit principle, we have to examine whether they perhaps serve as steering taxes so that they might find their justification in this way.

Let us first turn to the problem of air pollution. It is true that, for quite some time, environmental aspects have played an important role in road traffic taxation in Germany. Since the reform of the motor vehicle tax in 1985 the emission of pollutants has been one of the factors which determine the tax rate for cars: From 1985 to 2009 only traditional pollutants were taken into account; since then the focus has been on $\mathrm{CO}_{2}$ emissions instead. As regards the motor vehicle tax on trucks, since 1994 the emission of traditional pollutants has been among the determinants of the tax rate. And since the ecological tax reform of 1999, at the latest, also the petroleum tax (now the energy tax) has explicitly been used to further the cause of the environment: Then, it was raised considerably in order to make the use of fossil fuels more expensive and thus to provide incentives for saving them. In addition, tax rates were differentiated according to the environmental impact of different fuels (leaded vs. unleaded gasoline; highsulfur vs. low-sulfur).

But, notwithstanding all political intentions, are the energy tax and the motor vehicle tax actually able to function as ecological steering taxes? As we have seen, in the case of road traffic, the obvious ecological objective is the reduction of emissions. If taxes are to be used at all to such purpose, they need to be emission taxes. And emission taxes as applied to the emissions of motor vehicles only make sense in the form of indirect emission taxes. Finally, an indirect emission tax is possible only in the case of $\mathrm{CO}_{2}$. It follows that the energy tax and the motor vehicle tax can be justified as ecological steering taxes only if they somehow function as $\mathrm{CO}_{2}$ emission taxes, that is, if there is a direct and proportional relation between $\mathrm{CO}_{2}$ emission and tax burden.
Obviously, this is - and cannot be the case with a mileage-independent tax like the motor vehicle tax. It is true that, as regards cars, the tax base includes $\mathrm{CO}_{2}$ emissions: explicitly in the form of the $\mathrm{CO}_{2}$-based part of the tax and implicitly in the part of the tax which is based on engine capacity (since fuel consumption and thus $\mathrm{CO}_{2}$ emissions tend to increase with engine capacity). However, it is not the relative $\mathrm{CO}_{2}$ emission (i.e. the emission per kilometer) but the absolute $\mathrm{CO}_{2}$ emission, which depends on mileage, that matters ecologically. The motor vehicle tax only takes the former into account - and even that in a very imprecise way because the "normal" $\mathrm{CO}_{2}$ emissions per kilometer which are used for tax purposes may differ a lot from the real $\mathrm{CO}_{2}$ emissions per kilometer on the road. In the case of trucks, $\mathrm{CO}_{2}$ emissions do not play any role at all. It follows that the motor vehicle tax cannot be regarded as a tax on $\mathrm{CO}_{2}$ emissions and is thus not an effective instrument to reduce these emissions. This conclusion will not be altered by the possible argument that, after all, the motor vehicle tax can be considered as an ecological steering tax because it discourages the acquisition of cars with large engine capacities and high $\mathrm{CO}_{2}$ emissions, and of trucks with "dirty" engines. However, these objectives do not make sense on their own but only insofar as they further the underlying objective of reducing emissions. And to attain this objective, there are instruments much more effective and much more efficient than the motor vehicle tax.

At first sight, things look different with the energy tax. As it taxes the consumption of fossil fuels it is, in principle, able to function as an indirect $\mathrm{CO}_{2}$ tax. However, for this to be the case, it would be necessary that the tax rates for the different fuels vary in proportion with their carbon content, that is, with the amount of $\mathrm{CO}_{2}$ released by their combustion. This condition is, at present, not fulfilled. Burning one liter of gasoline (diesel) releases $2.33 \mathrm{~kg}(2.63 \mathrm{~kg})$ of $\mathrm{CO}_{2}[19 ; 20]$. Therefore, the energy tax on gasoline of $€ 0.6545$ per liter corresponds to a $\mathrm{CO}_{2}$ tax of $€ 0.2809$ 
per kilogram, whereas the energy tax on diesel of $€ 0.4704$ per liter is equivalent to a $\mathrm{CO}_{2}$ tax of $€ 0.1783$ per kilogram. (The energy tax on natural gas of $€ 13.90$ per MWh of thermal value is equivalent to a $\mathrm{CO}_{2}$ tax of $€ 0.0706$ per kilogram, because burning one MWh of natural gas releases $197 \mathrm{~kg}$ of $\mathrm{CO}_{2}$.) Its tax rates being not proportional to carbon content, the energy tax cannot be regarded as an indirect tax on $\mathrm{CO}_{2}$ emissions.

We have to conclude that neither the motor vehicle tax nor the energy tax can be justified as an ecological steering tax.

Besides air pollution, the other major cause of traffic-related externalities is congestion. Are the truck toll or the infrastructure charge in any way able alleviate this problem and thus to have some kind of allocative function? The answer clearly is no. From all that we have learned about the truck toll and the infrastructure charge, it should be obvious that neither can in any way function as a congestion charge.

To summarize, the German "system" of road traffic taxation does not in the least correspond to the principles of taxation and is therefore in dire need of reform.

\section{A proposal for reform}

What would a reform of German road traffic taxation look like? As shown above, road traffic ought best to be taxed as follows: There ought to be a $\mathrm{CO}_{2}$ emission tax which is to function as a steering tax; and there ought to be a comprehensive toll which is both to raise revenue according to the benefit principle and to alleviate traffic congestion in its capacity as a steering tax. To get anywhere close to such a system, traffic taxation in Germany needs to be reformed considerably.

\section{Part one of the reform: energy tax and motor vehicle tax}

The first part of the reform would have to look as follows: On the one hand, the motor vehicle tax is to be abolished; under no circumstances can it be an instrument to reduce $\mathrm{CO}_{2}$ emissions effectively and efficiently. On the other hand, the rates of the energy tax have to be adapted to the specific $\mathrm{CO}_{2}$ emissions of the different fossil fuels. If the ecological objective were not to be climate stabilization but resource conservation, the energy tax rates would have to reflect the energy content or the thermal value of the different fossil fuels (such a proposal is made by, e.g., [21]).

If one takes as given, e.g. the energy tax rate for gasoline of $€ 0.6545$ per liter, which is equivalent to a $\mathrm{CO}_{2}$ tax of $€ 0.2809$ per kilogram, the energy tax on diesel would have to be raised to $€ 0.7388$ per liter. It goes without saying that the tax rates for the other fossil fuels which are used for road traffic would also have to be adapted correspondingly (in the case of natural gas this would imply a tax raise to $€ 55.34$ per MWh or $€ 0.7122$ per kilogram). In this way, the energy tax would burden all road-traffic related $\mathrm{CO}_{2}$ emissions uniformly and thus function as an efficient and, depending on the $\mathrm{CO}_{2}$ tax rate, effective $\mathrm{CO}_{2}$ tax. Finally, it would be justifiable as a steering tax, to wit, an ecological steering tax.

But what other consequences would our proposal have? From a fiscal point of view, the additional revenue due to the higher taxation of diesel would certainly be welcome (due to their very low market shares, possible tax hikes for other fossil fuels would only lead to insignificant additional revenue). Of course, the fiscal effect can be varied by adjusting the $\mathrm{CO}_{2}$ tax rate. It is not the absolute rate as such that is crucial for the energy tax to function as a $\mathrm{CO}_{2}$ tax but the fact that there is a uniform rate for all fossil fuels. Assuming, as is usual, that the energy tax is completely shifted forward, the price of diesel would rise by $€ 0.2684$ per liter before VAT and by $€ 0.3194$ per liter after VAT. On the basis of the 2016 sales figure (44.321 billion of liters) energy tax revenue would increase by $€ 11.896$ billion (this amount and those following were calculated on the basis of [3] and [4]). If the business share (household share) of diesel consumption is taken to be $75 \%(25 \%)$, there would also be additional VAT revenue (the VAT applying to the increase of the net price of diesel times the household share in total diesel sales) 
of $€ 0.565$ billion. The percentages of $25 \%$ and $75 \%$ are derived as follows: Transport companies with their trucks account for about $50 \%$ of total diesel consumption [22, p. 53] so that the other $50 \%$ are due to cars. Assuming that half of the latter 50\% is used by businesses will result in the above-mentioned percentages. With total additional tax revenue of $€ 12.461$ billion, the loss of the motor vehicle tax revenue, which in 2016 amounted to $€ 8.952$ billion, would be more than compensated; all in all, there would be net additional revenue of $€ 3.509$ billion.

However, it is to be expected that the considerable increase in the price of diesel, which would result from the suggested tax hike, would have consequences for the demand for diesel. In general, the price elasticity of demand for fuels in Germany is thought to be rather low - at least in the short run. For example, Boysen-Hogrefe [23] assumes values of -0.2 and -0.5 as the lower and the upper limit, respectively, to this price elasticity. If we choose the intermediate value of -0.35 for the demand for diesel, the fiscal effects of our proposal would change as follows: Because of the tax hike, the price of diesel, which stood, at the time of writing, at about $€ 1.26$ per liter (VAT included), would rise by $25.3 \%$, so that demand for diesel would decrease by $8.9 \%$, that is, from 44.321 billion liters to 40.377 billion liters (the relative price increase applies both to the price before and after VAT; therefore, the relative decrease in demand is assumed to be the same for business and household demand). This fall in demand by 3.944 billion liters would reduce the additional revenue of $€ 11.896$ billion from the higher energy tax on diesel and of $€ 0.565$ billion from the VAT to $€ 8.982$ billion and $€ 0.427$ billion, respectively, which would sum up to $€ 9.409$ billion - still in excess of the revenue loss from the abolition of the motor vehicle tax by $€ 0.457$ billion.

There would not be any distributional conflicts within the federal fiscal system of Germany: Both the energy tax and the motor vehicle tax are federal taxes so that neither states nor local governments would be affected - except through their share in the additional VAT revenue. In our example, the federal government, whose share in VAT revenue is currently $53.3 \%$, would expect total additional revenue of $€ 0.231$ billion (the difference between additional energy tax revenue and the loss of motor vehicle tax revenue: $€ 0.003$ billion; plus the federal share in the additional VAT revenue: $€ 0.228$ billion); state and local governments together would receive additional VAT revenue of $€ 0.199$ billion.

In the longer run, the energy tax revenue can be expected to decline in as much as mileage would be reduced and fuel-saving vehicles or vehicles with alternative drives would be more and more in demand. But this effect would have been intended and would be evidence that the $\mathrm{CO}_{2}$ tax functions as it is supposed to.

While the revenue increase would thus not be lasting, there would be another important effect which would be permanent: As the motor vehicle tax is, in contrast to the energy tax, levied directly from consumers, that is, the holders of motor vehicles, and as it thus is very costly to administer [24], its abolition would save a considerable amount of administration costs. On the other hand, the proposed change in the energy tax would hardly involve any costs at all.

Besides, the proposed reform would lead to considerable distributional effects among the group of vehicle owners. Owners of gasoline cars would profit from the abolition of the motor vehicle tax whereas owners of diesel cars and of trucks would have to pay the higher energy tax on diesel which, depending on mileage, could more than outweigh the savings related to the motor vehicle tax so that, for them, the reform could result in a net loss. As a rule, the mileage for such a net loss to occur would increase with the size and thus the fuel consumption of the vehicle. Let us compare, for example, two diesel cars: a subcompact (Mercedes A160d: $107 \mathrm{~g} \mathrm{CO}_{2} / \mathrm{km}$; norm consumption $4.1 \mathrm{l} / 100 \mathrm{~km}$; motor vehicle tax $€ 166.00)$ and a full-size sedan (Mercedes S400d: $139 \mathrm{~g} \mathrm{CO}_{2} / \mathrm{km}$; norm consumption $5.4 \mathrm{l} / 100 \mathrm{~km}$; motor vehicle tax 
$€ 373.00)$. The owner of the former would suffer a net loss due to the proposed reform if his annual mileage were in excess of 12,700 kilometers, whereas the latter would find himself at a disadvantage only if he drove more than $21,600 \mathrm{~km}$ per year. In this example, it was assumed that the cars were owned by households and that the price of diesel would rise by $€ 0.3194$ per liter (after VAT). As the realistic on-the-road consumption is virtually always higher than the norm consumption, the mileages calculated are upper limits; in effect, drivers of diesel cars would incur losses at lower mileages in most cases.

Business owners of diesel cars who typically have high to very high mileages would therefore almost always be among the losers of the tax reform. This is even more true for transport companies: The trucks that they operate have a much higher mileage and a much higher consumption than diesel cars, whereas the motor vehicle tax - and thus the amount saved due to its abolition - is not higher in the same proportion.

It is this consequence of the first part of our proposal that will be the main obstacle to its realization: German transport companies, especially long-haul transport companies, would become less competitive in comparison with foreign companies.

\section{Part two of the reform: truck toll and infrastructure charge}

According to our deliberations above, both the truck toll and the infrastructure charge ought to be merged into a new and comprehensive toll. There ought to be a base rate per kilometer which would depend on vehicle weight. As almost all damage to roads is attributable to (heavy) trucks, the rate for trucks would be higher than that for cars by orders of magnitude. For all practical purposes, four base rates (one for cars, one for light trucks, one for heavy trucks, and one for heavy trucks with trailers) would suffice. In addition to this user fee, there ought to be a surcharge for the use of heavily travelled roads in urban areas which would vary with the days of the week and the hour of the day. Again, one would want to have only a couple of different rates so that the tariff does not become too complicated and thus the surcharge too unpredictable. This combined toll would be collected electronically by way of GPS-enabled transponders in all vehicles. Technically, this would be no problem at all; also, the cost would not be too high. However, there are considerable political obstacles. Privacy concerns, mistrust of "big government" and fear of data abuse would make the introduction of such a toll an uphill battle - which would be hard to win especially in Germany where data protection is considered very important.

Therefore, the chance for this part of our reform proposal to be realized soon are rather slim indeed. For political reasons it would seem appropriate that at first only part one of the reform proposal be realized. Until safeguards will have been devised which ensure privacy and the protection of drivers' data, and until sufficient political support for the second part will have been built, the present truck toll and the soon-to-come infrastructure charge would be left in place. In that way, truck owners would continue to contribute to the cost of road infrastructure and in that way, also car owners would at least get used to the idea of paying some kind of toll or user fee. (Other authors propose second-best solutions in which the vehicle tax partly compensates for the inability to impose a toll depending on mileage; see, e.g., $[25 ; 26]$.)

\section{The European perspective}

Nowadays, member countries of the European Union are no longer completely free to carry out political reforms. They have to make sure that these reforms are compatible with European law.

In the Energy Taxation Directive (Annex I) of the European Commission, minimum rates for motor fuels are established. There is, however, no further harmonization and member states are free to apply higher rates. In fact, rates differ considerably within the European Union [27]. German rates are above the EU av- 
erage; its gasoline rate is the ninth highest and its diesel rate is the sixth highest. Therefore, as mentioned above, the unilateral introduction of a $\mathrm{CO}_{2}$ tax - and the rise in the price of diesel consequent upon it - would cause problems for the German transport companies. If only for this reason, a European approach to the introduction of a $\mathrm{CO}_{2}$ tax would clearly be desirable - although it would not be necessary according to the law of the European Union (there are also other reasons for a coordinated reform; see Conclusion).

Also a comprehensive toll system if and when it is finally installed - will have to comply with European law. As of today, the existing European legislation on tolls only covers trucks (permissible total weight of more than $3,500 \mathrm{~kg}$ ): the directive 1999/62/EC as modified by the directives 2006/38/EC and 2011/76/ EU. As regards cars, there is only a "Communication from the Commission on the Application of National Road Infrastructure Charges Levied on Light Private Vehicles" (COM 2012/199 of May 14 $4^{\text {th }}, 2012$ ) in which member states are enjoined to obey the principles of non-discrimination and proportionality, if and when they establish toll schemes for cars (it is the principle of non-discrimination that the German infrastructure charge is accused of violating). Furthermore, in the directive 2004/52/EC, the European Commission envisages a "European Electronic Toll System" which is to realize the principle of inter-operability. This means that a single on-board unit is to be used by drivers throughout the EU to pay any national tolls. Thus, not only is there nothing in EU law that would prohibit a comprehensive toll system for both trucks and cars, some such system and the technical means for its implementation are actually promoted by the European Commission. As, of course, also foreign road users would be supposed to pay this toll (just like drivers of foreign trucks have to pay the truck toll in Germany today), coordination between the EU member states would be highly desirable, although, again, it would not be required by law.
In any case, both parts of our reform proposal do not seem to conflict with European law. After all, this was to be expected because the transport policy of the European Union is guided by the "user pays" and the "polluter pays" principle [28] - principles that correspond with and can be derived from the first and the second of our principles of taxation, respectively.

\section{Conclusion}

It has been shown that the taxation of road traffic in Germany is not compatible with generally accepted principles of taxation and, therefore, ought to be reformed. Taxes on road traffic can be justified as fiscal taxes to raise revenue according to the benefit principle and as steering taxes to deal with environmental issues and congestion. Consequently, a reform has been proposed which would, on the one hand, replace the truck toll and the infrastructure charge with a comprehensive toll and, on the other, abolish the motor vehicle tax and transform the energy tax into a tax on $\mathrm{CO}_{2}$ emissions. In order for German transport companies not to suffer competitive disadvantages from the unilateral introduction of a $\mathrm{CO}_{2}$ tax and for traffic flow in Europe not to be impeded by uncoordinated national tolls, such a reform ought to be carried out on the European level.

In the context of such a European solution one also could - and ought to abandon the regulation of $\mathrm{CO}_{2}$ emissions of cars and light trucks (there are no $\mathrm{CO}_{2}$ standards for heavy trucks) which not only would become superfluous if $\mathrm{CO}_{2}$ emissions were taxed but which also would distort the economic incentives due to such a $\mathrm{CO}_{2}$ tax. In particular, it is possible that $\mathrm{CO}_{2}$ standards might actually increase total vehicle miles travelled [12, p. 388]. And of course one would wish to see a systematization of climate policy in general: Only when the burden on all $\mathrm{CO}_{2}$ emissions, no matter their source, is - at least approximately - equal, can a cost-efficient climate policy be realized. Towards this goal, the proposed reform of the energy tax would but be a first, albeit an important, step. 


\section{References}

1. Anon. Der Dieselskandal setzt Angela Merkel unter Druck. Rheinische Post online, 12.8.2017. Available at: http:// www.rp-online.de/politik/deutschland/diesel-skandal-angelamerkel-unter-druck-aid-1.7007702.

2. Dudenhöffer F. Verfahrene Regulierungspolitik und $\mathrm{CO}_{2}$-Strafzahlungsrisiken für Autobauer. ifo Schnelldienst, 2017, vol. 70, no. 3, pp. 23-27.

3. Statistisches Bundesamt. Energiesteuerstatistik. Fachserie 14, Reihe 9.3. Wiesbaden, 20082017. (In German).

4. Statistisches Bundesamt. Finanzen und Steuern - Steuerhaushalt 2. Vierteljahr 2017. Fachserie 14, Reihe 4. Wiesbaden, 2017.

5. Bundesfinanzministerium. Geschäftsstatistik Kraftfahrzeugsteuer. Berlin, 2013. Available at: http:// www.bundesfinanzministerium.de/Content/DE/Monatsberichte/2013/03/Inhalte/ Kapitel-4-Analysen/4-3-geschaeftsstatistik-kraftfahrzeugsteuer.html.

6. Jaenichen S. Verkehrswegegebühren und Ausländerdiskriminierung. Wirtschaftsdienst, 2015, vol. 95, no. 1, pp. 32-38. (In German).

7. Hyman D. N. Public Finance. South-Western. Mason, 2005.

8. Musgrave R. A., Peggy B. Musgrave. Public Finance in Theory and Practice. $4^{\text {th }}$ ed. McGrawHill. New York, 1984.

9. Homburg S. Allgemeine Steuerlehre. $7^{\text {th }}$ ed. Vahlen. München, 2015.

10. Baumol W. J., Oates W. E. The Use of Standards and Prices for Protection of the Environment. Swedish Journal of Economics, 1971, vol. 73, no. 1, pp. 42-54.

11. Leontyeva Yu. V., Mayburov I. A. Theoretical framework for building optimal transport taxation system. Journal of Tax Reform, 2016, vol. 2, no. 3, pp. 193-207.

12. Parry I.W.H., Walls M. Harrington W. Automobile Externalities and Policies. Journal of Economic Literature, 2007, vol. 45, no. 2, pp. 373-399.

13. Baumol W. J., Oates W. E. The Theory of Environmental Policy. $2^{\text {nd }}$ ed. Cambridge University Press. Cambridge, 1998.

14. Perman R., et al. Natural Resource and Environmental Economics. $4^{\text {th }}$ ed. Pearson. Harlow, 2011.

15. Endres A. Umweltökonomie. $4^{\text {th }}$ ed. Kohlhammer. Stuttgart, 2013.

16. Heywood J. B. Internal Combustion Engine Fundamentals. $2^{\text {nd }}$ ed. McGraw-Hill. New York, 2018.

17. Schreiner K. Verbrennungsmotoren. In Böge A., Wolfgang B. (eds), Handbuch Maschinenbau, 23 $3^{\text {rd }}$ ed., Springer Vieweg. Wiesbaden, 2017, pp. 1133-1197.

18. Adolf J. Mineralölsteuer - Stütze unseres Steuersystems oder Auslaufmodell. Wirtschaftsdienst, 2003, vol. 83, no. 7, pp. 460-468.

19. Schobert H. H. Chemistry of Fossil Fuels and Biofuels. Cambridge University Press. Cambridge, 2013.

20. Umweltbundesamt. $\mathrm{CO}_{2}$-Emissionsfaktoren für fossile Brennstoffe. Dessau, 2016.

21. Dudenhöffer F. Diesel-PKW sind weniger umweltfreundlich als behauptet. ifo Schnelldienst, 2017, vol. 70, no. 10, pp. 27-29.

22. Shell Deutschland Oil GmbH. Shell LKW-Studie. Hamburg, 2010.

23. Boysen-Hogrefe J. Der Einfluss des Erdölpreises auf die Energiesteuerprognose. ifw Working Paper 1849. Kiel, 2013.

24. Rappen H. Die Kfz-Steuer - ein Relikt? Wirtschaftsdienst, 2006, vol. 86, no. 6, pp. 382-290.

25. Bjertnæs G.H.M. The Efficient Combination of Taxes on Fuel and Vehicles. CESifo Working Paper 6789. Munich, 2017.

26. Fullerton D., West S. E. Tax and subsidy combinations for the control of car pollution. B.E. Journal of Economic Analysis and Policy, 2010, vol. 10, no. 1, pp. 1-33.

27. European Environmental Agency. Transport Fuel Prices and Taxes. Brussels, 2017. Available at: https://www.eea.europa.eu/data-and-maps/indicators/fuel-prices-and-taxes/ assessment-7.

28. European Commission. Road Charging. Brussels, 2018. Available at: https://ec.europa. eu/transport/modes/road/road_charging_en.

\section{Acknowledgements}

The helpful comments of Igor Mayburov and two anonymous referees are gratefully acknowledged

\section{Благодарности}

Автор признателен Игорю Майбурову и двум анонимным рецензентам за полезные комментарии 


\section{Author}

Fritz Söllner - Doctor of Economic Sciences, Professor, Head of the Department of Public Finance, Ilmenau Technical University (26 Ehrenberg St., 98693, Ilmenau, Germany); ORCID: 0000-0003-1047-6662; e-mail: fritz.soellner@tu-ilmenau.de

\section{Информация об авторе}

Фрии Зольнер - доктор экономических наук, профессор, руководитель департамента публичных финансов, Технический университет Ильменау (98693, Германия, Ильменау, Ирнбергштрассе, 26); ORCID: 0000-0003-10476662; e-mail: fritz.soellner@tu-ilmenau.de

\section{For citation}

Söllner F. Road traffic taxation in Germany: the present system, its problems and a proposal for reform. Journal of Tax Reform, 2018, vol. 4, no. 1, pp. 57-72. DOI: 10.15826/ jtr.2018.4.1.045

\section{Аия цитирования}

Золльнер Ф. Налогообложение дорожного движения в Германии: современные проблемы и планы реформирования / Ф. Золльнер / / Journal of Tax Reform. 2018. - T. 4, № 1. - C. 57-72. - DOI: 10.15826/jtr.2018.4.1.045

\section{Article info}

Received February 22, 2018; accepted March 29, 2018

\section{Информация о статье}

Дата поступления 22 февраля 2018 г.; дата принятия к печати 29 марта 2018 г. 